\title{
Analisis Kualitas Air pada Kawasan Budidaya Rumput Laut Eucheuma Cottoni di Kabupaten Jeneponto
}

\section{Water Quality Analysis In The Eucheuma Cottoni Seaweed Cultivation Area In Jeneponto District.}

Andi Atmanisa, Program Studi Pendidikan Teknologi Pertanian Fakultas Teknik,Universitas Negeri Makassar.Email: andiatmanisa13@gmail.com

Amirah Mustarin, Program Studi Pendidikan Teknologi Pertanian Fakultas Teknik, Universitas Negeri Makassar. Email: amirah.mustarin@unm.ac.id

Nur Anny S Taufieq, Program Studi Pendidikan Teknologi Pertanian Fakultas Teknik, Universitas Negeri Makassar. Email: nurannytaufieq@yahoo.co.id

\begin{abstract}
Abstrak
Penelitian ini bertujuan untuk mengetahui Kualitas Air pada Kawasan Budidaya Rumput Laut Eucheuma cottoni di Kabupaten Jeneponto yang terkait dengan parameter fisika, kimia dan biologi. Penelitian ini merupakan jenis penelitian deskriptif dengan menggunakan metode survei, penelitian ini dilakukan dengan mengambil sampel air pada dua stasiun berbeda yakni, Desa Tanrusampe dan Desa Bontosunggu, Kabupaten Jeneponto pada musim hujan. Hasil penelitian ini menunjukkan bahwa kualitas air stasiun 1 (Desa Tanrusampe) meliputi suhu, kecerahan, kecepatan arus, $\mathrm{pH}$, salinitas, oksigen terlarut, fosfat dan plankton masih dalam kategori normal dan masih berada pada ambang batas kualitas air perairan, sedangkan nitrat sudah dalam faktor pembatas atau kandungan nitratnya bersifat toksik. Sedangkan kualitas air pada stasiun 2 (Desa Bontosunggu) masih berada pada ambang batas kualitas air perairan, dan masih layak untuk budidaya rumput laut Eucheuma cottoni. Diharapkan pada penelitian selanjutnya Analisis Kualitas Air pada Kawasan Budidaya Rumput Laut Eucheuma cottoni di Kabupaten Jeneponto pada musim kemarau sehingga data yang diperoleh lebih akurat dan memberikan pengetahuan kepada masyarakat di masa mendatang.
\end{abstract}

Kata kunci: Rumput Laut, Fisika, Kimia, Biologi, Jeneponto

\begin{abstract}
This study aims to determine the Water Quality in Eucheuma cottoni Seaweed Cultivation in Jeneponto Regency related to physical, chemical and biological parameters. This research is a type of descriptive research using survey methods, this research was conducted by taking water samples at two different stations namely, Tanrusampe Village and Bontosunggu Village, Jeneponto Regency during the rainy season. The results of this study indicate that the water quality of Station 1 (Tanrusampe Village) includes temperature, brightness, current speed, pH, salinity, dissolved oxygen, phosphate and plankton are still in the normal category and are still within the water quality threshold, while nitrate is already in the factor the limiting or nitrate content is toxic. While the water quality at station 2 (Bontosunggu Village) is still at the water quality threshold, and is still suitable for Eucheuma cottoni seaweed cultivation. It is hoped that in future studies, Water Quality Analysis in the Eucheuma cottoni Seaweed Cultivation Area in Jeneponto Regency in the dry season so that the data obtained is more accurate and provides knowledge to the public in the future.
\end{abstract}

Keywords: Keywords: Seaweed, Physics, Chemistry, Biology, Jeneponto 


\section{LatarBelakang}

Kabupaten Jeneponto sebagai salah satu tempat pengembangan budidaya rumput laut yang berada pada wilayah pantai barat Sulawesi Selatan yang mempunyai potensi untuk pengembangan rumput laut. Kabupaten Jeneponto sesuai potensinya yang ditunjang oleh tujuh kecamatan daerah pesisir dengan panjang garis pantai sekitar $95 \mathrm{~km}$, ditetapkan sebagai pusat pengembangan (inkubator) agribisnis perikanan dan rumput laut (Febriani, 2014). Kegiatan budidaya rumput laut di Kabupaten Jeneponto ini sudah berlangsung cukup lama dan terus berkembang sampai saat ini.

Kegiatan budidaya rumput laut menjadi harapan masyarakat untuk memperbaiki kondisi ekonomi masyarakat yang selama ini identik dengan kemiskinan, meskipun tidak jarang ada kendala-kendala yang masih sering kali ditemui oleh masyarakat yang mengembangkannya, misalnya disebabkan kualitas air, kondisi lingkungan seperti masyarakat yang ada dipesisir laut membuang sampah sembarangan di pesisir laut serta cuaca yang tidak mendukung sehingga harga rumput laut menjadi tidak stabil.

Kualitas air merupakan salah satu faktor yang memegang peranan penting terhadap keberhasilan suatu usaha budidaya rumput laut. Kualitas air merupakan persyaratan yang harus diperhatikan dalam budidaya rumput laut. Rumput laut sebagai tanaman memerlukan nutrien dari air laut untuk tumbuh. Unsur utama yang banyak dibutuhkan adalah nitrat dan fosfat. Kedua unsur tersebut sering digunakan sebagai pupuk. Pertumbuhan dan perkembangan rumput laut sangat diperlukan kualitas cahaya serta zat hara yang cukup seperti nitrat dan fosfat, ini diperlukan sebagai bahan dasar penyusunan protein dan pembentukan klorofil dalam proses fotosintesis (Aslan, 1998).

Rumput laut jenis Eucheuma cottoni hidup dengan cara menyerap nutrien dari laut dan melakukan fotosintesis, sehingga membutuhkan faktor-faktor fisika, kimia dan biologis laut seperti, salinitas, $\mathrm{pH}$, kecerahan, suhu, nitrat, dan fosfat serta pencahayaan sinar matahari untuk pertumbuhan plankton, sehingga diperlukan penelitian mengenai analisis kualitas air pada kawasan budidaya rumput laut Eucheuma cottoni di Kabupaten Jeneponto.

\section{Tujuan Penelitian}

Tujuan pada penelitian ini adalah untuk mengetahui kualitas air pada kawasan budidaya rumput laut Eucheuma cottoni di Kabupaten Jeneponto yang terkait dengan parameter fisika, kimia dan biologi.

\section{Bahan dan Metode}

Penelitian ini merupakan jenis penelitian deskriptif dengan menggunakan metode survei, penelitian ini dilakukan dengan mengambil sampel air pada dua stasiun berbeda yakni, Desa Tanrusampe dan Desa Bontosunggu, Kabupaten Jeneponto pada musim hujan.

\section{Waktu}

Penelitian ini dilaksanakan pada bulan Juni-Juli 2019 dengan persiapan penelitian meliputi observasi tempat penelitian dan keperluan mengambil data.

\section{Tempat}


Penelitian ini dilakukan di Desa Tanrusampe dan Desa Bontossunggu, Kabupaten Jeneponto.

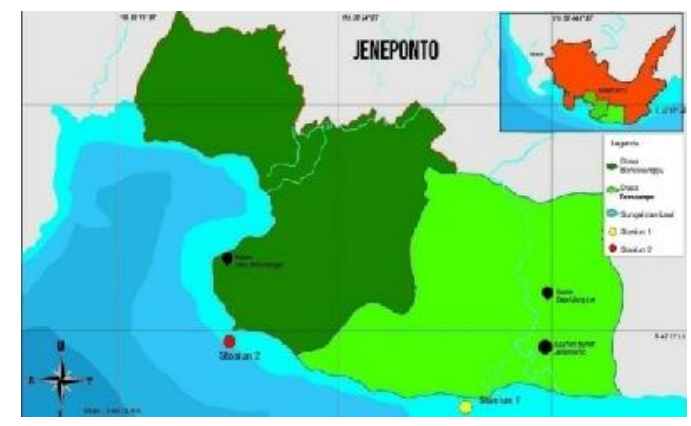

Pengambilan sampel dilakukan pada dua lokasi yakni:

1. Titik pengambilan sampel 1 di Desa Tanrusampe Kecamatan Binamu

2. Titik pengambilan sampel 2 di Desa Bontosunggu KecamatanTamalatea

Pengujian aspek kimia yang meliputi fosfat, nitrat dan aspek biologi yaitu plankton dilakukan di laboratorium kualitas air Fakultas Perikanan dan Kelautan Universitas Hasanuddin Makassar.

\section{Alat dan bahan}

Botol sampel, Sechi disk, $\mathrm{pH}$ meter, Do meter, Thermometer, Refraktometer, Layang-layang arus, Plankton net, Coolbox, Pelampung, alat tulis menulis, dan kamera.

Bahan yang digunakan dalam penelitian ini adalah air laut, aquades, dan lugol.

\section{Prosedur Penelitian}

\section{Suhu}

Pengujian suhu dilakukan dengan sebagai berikut :
a. Pengukuran suhu dilakukan setiap hari pukul 08:00
b. Pengambilan sampel air pada lokasi yang telah ditentukan .

c. Pengujian suhu dilakukan dengan cara sebagai berikut :

3. Termometer langsung dicelupkan ke dalam contoh uji dan biarkan 2 menit sampai dengan 5 menit
1) sampai termometer menunjukkan nilai yang stabil;
2) Catat pembacaan skala termometer tanpa mengangkat lebih dahulu termometer dari air.

2. $p H$

a. Pengukuran $\mathrm{pH}$ dilakukan setiap hari pukul 08:00

b. Lakukan kalibrasi alat pH-meter dengan larutan penyangga sesuai dengan instruksi kerja alat. Kondisikan contoh uji sesuai dengan suhu kamar.

c. Keringkan dengan kertas tisu selanjutnya bilas elektroda dengan air suling.

d. Bilas elektroda dengan contoh uji.

e. Celupkan elektroda kedalam contoh uji sampai pH-meter menunjukan pembacaan angka yang tetap.

f. Catat hasil pembacaan skala

3. Oksigen Terlarut

a. DO meter dikalibrasi terlebih dahulu pada skala nol

b. Celupkan ujung probe pada sampel

c. Tunggu pembacaan alat sampai angka yang ditunjukkan stabil

\section{Kecerahan}

a. Celupkan sechi disk kedalam air laut, kemudian perhatikan kenampakannya

b. Berikan tanda pada tali sechi disk sesuai dengan kenampakan sechi disk

c. Ukur panjang kedalaman tali sechi disk, kemudian hasilnya dicatat

\section{Salinitas}

a. Pertama pengukuran salinitas dengan menggunakan refraktometer yaitu kalibrasi kaca prisma dengan menggunakan aquades. 
b. Bersihkan dengan tissue dengan satu arah.

c. Tetesi kaca prisma sebanyak kurang lebih 3 tetes air sampel (air laut) dengan menggunakan pipet tetes.

d. Kemudian tutup kaca prisma dengan tingkat kemiringan $45^{\circ}$ agar tidak terbentuk gelembung udara pada kaca prima.

e. Arahkan refraktometer pada cahaya matahari.

f. Amati dan baca skalanya pada sebelah kanan.

g. Kemudian catat hasilnya.

6. Kecepatan arus

a. Layang-layang arus dilepaskan ke perairan.

b. Hitung waktu pelepasan layanglayang arus ke perairan hingga tali meregang dengan bantuan stopwatch.

c. Hitung kecepatan arus dengan menggunakan rumus.

$$
v=\frac{S}{T}
$$

d. Catat hasilnya.

\section{Teknik Analisis Data}

Teknik analisis data yang digunakan dalam penelitian ini yaitu analisis deskriptif. Data yang diperoleh merupakan data yang bersumber dari hasil observasi dan pengamatan selama penelitian.

\section{Hasil dan Pembahasan}

\section{Suhu}

Hasil pengukuran suhu yang telah dilakukan pada kawasan budidaya rumput laut (Eucheuma cottoni) diperoleh nilai suhu terendah yaitu $26^{\circ} \mathrm{C}$ minggu keempat dan kelima pada stasiun 1 dan stasiun 2 sedangkan nilai suhu tertinggi di minggu pertama sampai minggu ketiga yaitu $27^{\circ} \mathrm{C}$ (Gambar 4.1).

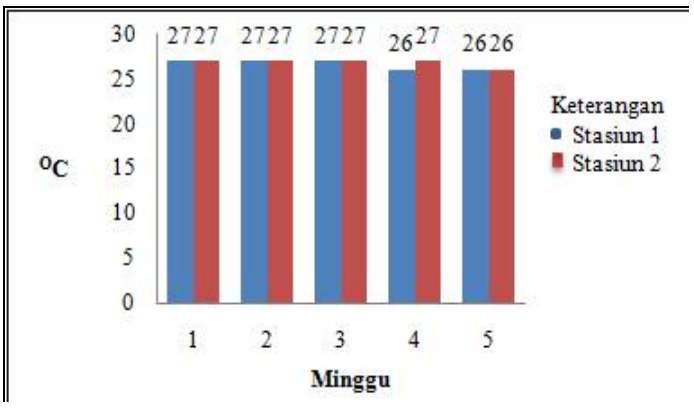

Gambar 4.1

Hasil Pengukuran Suhu Setiap Minggu

Kisaran suhu yang terukur selama penelitian pada stasiun 1 dan stasiun 2 masih kisaran suhu yang baik untuk budidaya rumput laut Eucheuma cottoni berdasarkan kriteria parameter fisika kimia untuk kesesuaian perairan budidaya rumput laut Eucheuma cottoni.

Perbedaan suhu disetiap stasiun dikarenakan waktu pengamatan dilakukan pada pukul 10.00 WITA pada stasiun 2 dan cuaca sedang cerah. Sejalan dengan pendapat Mujizat (2010), suhu air yang tinggi akibat waktu pengambilan sampel yang semakin siang, maka suhu semakin naik karena pada waktu siang hari perairan semakin panas dan adanya penyerapan cahaya oleh air akan menyebabkan terjadinya lapisan air yang mempunyai suhu yang berbeda-beda. Perbedaan suhu di setiap stasiun disebabkan oleh penyinaran matahari dan kecepatan angin yang mempengaruhi pergerakan suhu air dari tempat satu ke tempat lainya. Menurut Juniarti (2017), perbedaan tinggi rendahnya suhu disebabkan pada lapisan permukaan suhu air cenderung dipengaruhi oleh angin. Semakin besar kecepatan angin yang ditimbulkan, maka semakin besar pencampuran suhu air. Suhu yang relatif tinggi juga disebabkan penyinaran matahari yang tinggi dan terus menerus sehingga membawa massa air 
bersuhu tinggi. Sejalan dengan pendapat Asni (2015) Suhu perairan yang tinggi akan mengakibatkan thallus rumput laut pucat kekuningan yang menjadikan rumput laut tidak tumbuh dengan baik. Sedangkan pada suhu rendah, membran protein dan lemak dapat mengalami kerusakan sebagai akibat terbentuknya kristal di dalam sel, sehingga mempengaruhi kehidupan rumput laut (Luning, 1990).

\section{Kecerahan}

Hasil pengukuran kecerahan yang telah dilakukan pada kawasan budidaya rumput laut (Eucheuma cottoni) diperoleh nilai kecerahan terendah yaitu $1 \mathrm{~m}$ minggu kelima pada stasiun 2 (Desa Bontosunggu) sedangkan nilai kecerahan tertinggi yaitu $1.5 \mathrm{~m}$ pada minggu pertama stasiun 2 , minggu kedua, ketiga dikedua stasiun dan minggu keempat di stasiun 1 (Desa Tanrusampe) (Gambar 4.2). Hasil kecerahan yang terukur selama penelitian pada stasiun 1 dan stasiun 2 masih kisaran kecerahan yang baik untuk budidaya rumput laut Eucheuma cottoni berdasarkan kriteria parameter fisika kimia untuk kesesuaian perairan budidaya rumput laut Eucheuma cottoni.

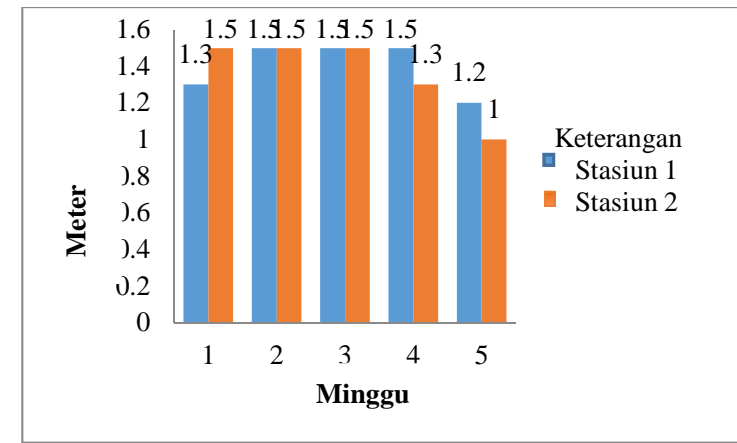

Gambar 4.2. Hasil Pengukuran Kecerahan Setiap Minggu

Semakin cerah suatu perairan berarti partikel-partikel lumpur yang kemungkinan terdapat dalam air semakin sedikit, sehingga memungkinkan cahaya yang masuk ke perairan semakin besar, yang selanjutnya intensitas cahaya yang besar akan menunjang proses fotosintesis rumput laut. Nilai kecerahan sangat dipengaruhi oleh keadaan cuaca, waktu pengukuran, kekeruhan serta ketelitian orang melakukan pengukuran (Effendi, 2003). Kecerahan perairan berhubungan erat dengan penetrasi cahaya matahari, kecerahan yang baik lebih dari 1 meter. Kondisi air yang jernih dengan tingkat transparansi tidak kurang dari 5 meter cukup baik untuk pertumbuhan rumput laut (Puslitbangkan, 1991).

\section{Kecepatan Arus}

Hasil pengukuran kecepatan arus yang telah dilakukan pada kawasan budidaya rumput laut (Eucheuma cottoni) diperoleh nilai kecepatan arus terendah yaitu $0.1 \mathrm{~m} / \mathrm{dt}$ minggu kedua pada kedua stasiun sedangkan nilai kecepatan arus tertinggi yaitu $0.18 \mathrm{~m} / \mathrm{dt}$ pada minggu kelima pada stasiun 1 (Desa Tanrusampe), ditunjukkan pada gambar Gambar 4.3. hasil pengukuran kecepatan arus yang terukur selama penelitian pada stasiun 1 dan stasiun 2 masih baik untuk budidaya rumput laut Eucheuma cottoni berdasarkan kriteria parameter fisika kimia untuk kesesuaian perairan budidaya rumput laut Eucheuma cottoni.

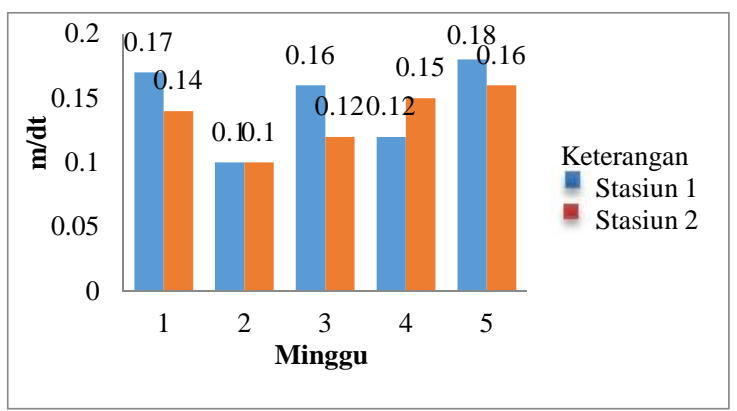

Gambar 4.3. Hasil Pengukuran Kecepatan Arus Setiap Minggu

Perbedaan kecepatan arus dapat disebabkan oleh arus pasang surut maupun 
karena angin dan ombak. Sejalan dengan pendapat Parenrengi et al., (2012), kecepatan arus yang baik untuk budidaya rumput laut adalah 20-40 cm/dt. Pada lokasi yang kaya nutrien, maka kecepatan arus yang lambat sekitar $10 \mathrm{~cm} / \mathrm{dt}$ sudah dapat mendukung pertumbuhan rumput laut yang baik, sebaliknya pada lokasi yang miskin nutrien diperlukan kecepatan arus yang lebih besar namun tidak melebihi $40 \mathrm{~cm} / \mathrm{dt}$. Dikatakan oleh Kotiya et al., (2011) bahwa arus mengontrol kesuburan lokasi untuk budidaya rumput laut.

Arus mempunyai peranan penting dalam pertumbuhan rumput laut. Jika arus terlalu pelan maka akan mengganggu penyerapan zat hara yang berada di perairan, selain itu arus yang pelan akan berdampak pada epifit-epifit yang tumbuh menempel pada rumput laut akan semakin banyak sehingga dapat menjadi kompetitor dalam mendapatkan nutrien (Arisandi, 2012). Arus yang terlalu tinggi juga dapat menyebabkan penyerapan unsur hara oleh rumput laut menjadi kurang maksimal. Sejalan dengan pendapat Indriani dan Sumiarsih (1991) arus yang baik untuk budidaya rumput laut berkisar antara 0,2 $0,4 \mathrm{~m} /$ detik, bila arus yang tinggi dapat dimungkinkan terjadi kerusakan tanaman budidaya, seperti dapat patah, robek, ataupun terlepas dari subtratnya. Perbedaan kecepatan arus disebabkan oleh letak lokasi, Adanya terumbu karang yang merupakan salah satu penyebab arus menjadi lemah, karena arus laut yang datang terhambat oleh barier yang dibentuk secara alami oleh terumbu karang. Pada saat yang lain adanya turbulensi dan perairan yang cukup terbuka merupakan pendugaan lain terjadi perbedaan kuat arus. Wibisono (2005) mengatakan bahwa setiap proses aktivitas pasang maupun surut menimbulkan arus, pada penelitian ini jangka penelitian yang singkat, sehingga arus lokal akibat akibat perbedaan pasang surut. Penelitian ini jangka penelitian yang singkat, sehingga arus yang terjadi merupakan arus lokal akibat perbedaan pasang surut. Kecepatan arus berperan penting dalam perairan, misalnya: pencampuran massa air, pengangkutan unsur hara, transportasi oksigen (Akib et al., 2015).

\section{4. $\mathbf{p H}$}

Tingkat keasaman (pH) yang diukur menggunakan $\mathrm{pH}$ meter diperoleh hasil yang tertinggi yaitu dengan rata-rata 7,7 , sedangkan nilai $\mathrm{pH}$ yang terendah yaitu rata-rata 7,6 ditunjukkan pada gambar 4.4. kisaran $\mathrm{pH}$ yang terukur selama penelitian pada stasiun 1 dan stasiun 2 masih kisaran $\mathrm{pH}$ yang normal untuk budidaya rumput laut Eucheuma cottoni berdasarkan kriteria parameter fisika kimia untuk kesesuaian perairan budidaya rumput laut Eucheuma cottoni .

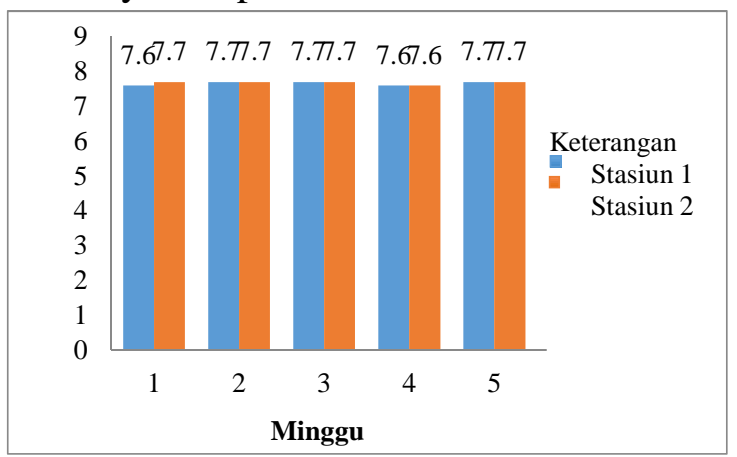

Gambar 4.4. Hasil Pengukuran pH Setiap Minggu

Perbedaan nilai $\mathrm{pH}$ dalam perairan salah satunya disebabkan oleh adanya perbedaan waktu pengukuran. Hasil penelitian memperlihatkan adanya perbedaan $\mathrm{pH}$ pada tiap lokasi pengambilan sampel, tetapi secara keseluruhan nilai rata-rata $\mathrm{pH}$ di perairan 
zona pemanfaatan budidaya rumput laut berada dalam kisaran yang mendukung untuk dilakukannya budidaya rumput laut. Sejalan dengan pendapat Wibowo (2012) derajat keasaman $(\mathrm{pH})$ yang baik untuk pertumbuhan optimal Eucheuma sp. Adalah 7 - 9 dengan kisaran optimum 7,3 8,2. Lebih lanjut Luning (1990) menyebutkan bahwa peningkatan nilai $\mathrm{pH}$ akan mempengaruhi kehidupan rumput laut dan kecenderungan perairan memiliki tingkat keasaman yang tinggi disebabkan masuknya limbah organik dalam jumlah besar. Sejalan dengan pendapat Ramdhan et al., (2018) pH perairan di dekat pantai terpantau lebih tinggi, hal ini berkaitan dengan aktivitas penduduk sekitar pantai banyak membuang limbah bersifat basa seperti deterjen dan sabun.

\section{Salinitas}

Hasil pengukuran salinitas pada kedua tempat berkisar antara 30-35 ppt. Hasil pengukuran salinitas pada setiap stasiun diperoleh nilai salinitas tertinggi yaitu pada stasiun 1 (Desa Tanrusampe) minggu ke empat dan stasiun 2 (Desa Bontosunggu) minggu kedua yaitu ratarata 35 ppt sedangkan nilai salinitas terendah yaitu rata-rata $30 \mathrm{ppt}$ pada kedua stasiun, ditunjukkan pada gambar 4.5.

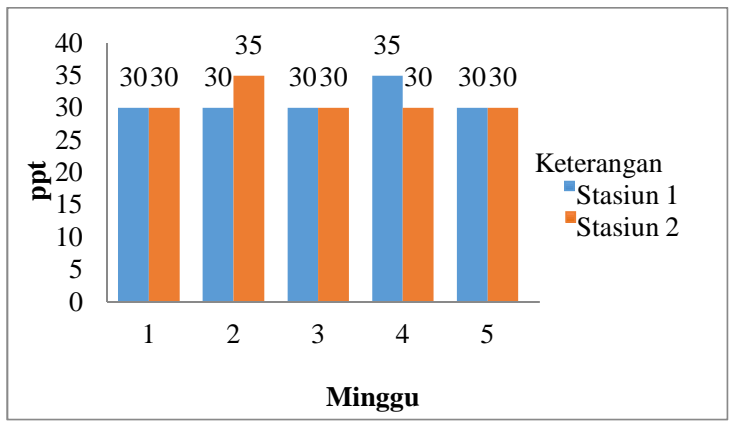

Gambar 4.5. Hasil Pengukuran Salinitas Setiap Minggu
Kisaran salinitas yang terukur selama penelitian di stasiun 1 dan stasiun 2 tersebut masih dalam kisaran yang dapat ditolerir sehingga mampu mendukung pertumbuhan rumput laut berdasarkan kriteria parameter fisika kimia untuk kesesuaian perairan budidaya rumput laut Eucheuma cottoni.

Adanya perbedaan salinitas disetiap stasiun dipengaruhi oleh beberapa faktor seperti sirkulasi air, penguapan, curah hujan, aliran sungai dan perbedaan waktu saat pengambilan sampel. Salinitas sangat berperan dalam pertumbuhan rumput laut K.alvarezii, Oleh karena itu, lokasi budidaya diusahakan berada jauh dari sumber air tawar seperti dekat muara sungai karena dapat menurunkan salinitas (Anggadiredja, 2011). Selanjutnya Aslan (1999) menyatakan bahwa rumput laut tidak dapat bertahan terhadap fluktuasi yang tinggi, salinitas yang baik berkisar antara 15-35 ppt. Hasil pengukuran salinitas di perairan jeneponto berkisar antara 30-35 ppt, maka salinitas pada perairan Jeneponto masih layak untuk budidaya rumput laut.

Spesies Eucheuma cottonii atau $K$. alvarezii merupakan jenis rumput laut yang bersifat stenohaline, tumbuhan ini tidak tahan terhadap fluktuasi salinitas yang tinggi, salinitas dapat berpengaruh terhadap proses osmoregulasi pada tumbuhan rumput laut. Hal ini sesuai dengan pendapat Patang (2010) Salinitas perairan untuk budidaya rumput laut berkisar antara 28-34 ppt (yang optimal sekitar 33 ppt).

\section{Oksigen Terlarut}

Hasil pengukuran oksigen terlarut pada kedua tempat berkisar antara 7,2- 7,5 ppm. Hasil pengukuran oksigen terlarut pada setiap stasiun diperoleh nilai oksigen 
terlarut tertinggi yaitu rata rata 7,5 ppm sedangkan nilai oksigen terlarut terendah yaitu rata-rata 7,2 ppm, ditunjukkan pada gambar 4.6. Hasil penelitian tersebut, menunjukkan bahwa kadar oksigen terlarut di stasiun 1 dan stasiun 2 masih baik untuk budidaya rumput laut Eucheuma cottoni berdasarkan kriteria parameter fisika kimia kesesuaian perairan budidaya rumput laut

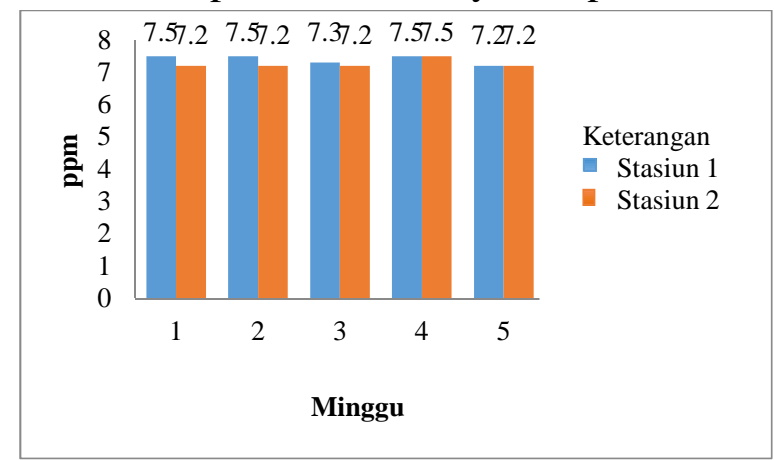

Gambar 4.6. Hasil Pengukuran Oksigen terlarut Setiap Minggu

Kadar oksigen di permukaan laut yang normal berkisar antara 5,7-8,5 ppm (Sutamihardja, 1978). Kadar oksigen terlarut dalam suatu perairan akan tinggi karena adanya sirkulasi arus di wilayah tersebut yang menyebabkan kandungan oksigen terlarut tinggi (Ramdhan et al., 2018). Kadar oksigen terlarut dalam suatu perairan akan menurun akibat proses pembusukkan bahan organik, respirasi, dan reaerasi terhambat (Andriani, 1999).

Faktor-faktor yang menurunkan kadar oksigen dalam air laut adalah kenaikan suhu air, respirasi (khusus pada malam hari), adanya lapisan minyak di atas permukaan laut dan masuknya limbah organik yang mudah terurai ke lingkungan laut. Untuk pertumbuhan rumput laut jenis Eucheuma cottonii dibutuhkan jumlah oksigen terlarut dalam perairan sebanyak 2 - 4 ppm, tetapi pertumbuhan lebih baik jika oksigen terlarut berada di atas 4 ppm (Indriani \& Sumiarsih, 1991).

\section{Fosfat}

Hasil penelitian menunjukkan kandungan fosfat $-\mathrm{PO}_{4}$ pada stasiun 1(Desa Tanrusampe) berkisar antara 4.277 $\mathrm{mg} / \mathrm{L}$ - $8.462 \mathrm{mg} / \mathrm{L}$. Sedangkan pada stasiun 2 (Desa Bontosunggu) berkisar antara $4.195 \mathrm{mg} / \mathrm{L} \quad-7.149 \mathrm{mg} / \mathrm{L}$. Berdasarkan hasil pengukuran parameter phospat - $\mathrm{PO}_{4}$ menunjukkan bahwa stasiun 1 (Desa Tanrusampe) dan stasiun 2 (Desa Bontosunggu) memiliki kadar kandungan fosfat $-\mathrm{PO}_{4}$ yang tinggi pada minggu kelima.

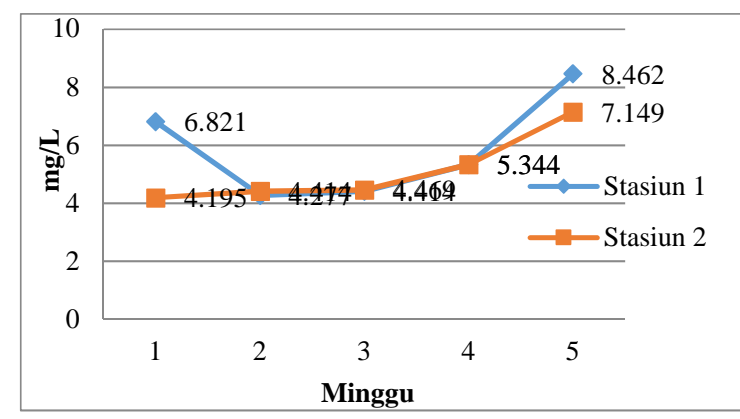

Gambar 4.7. Hasil Pengukuran Fosfat Setiap Minggu

Konsentrasi fosfat yang di butuhkan untuk pertumbuhan alga berkisar antara 0.018-0.090 ppm dan batas tertinggi adalah $\quad 8.90-17.8$ ppm $\left(\mathrm{P}_{-} \mathrm{PO}_{4}\right)$ jika nitrogen dalam bentuk nitrat. Penyebab tingginya fosfat adalah gelombang laut yang terlihat secara langsung pada daerah budidaya rumput laut cukup besar yang bisa menyebabkan pengadukan massa air dan mengangkat kandungan fosfat yang terdapat di dasar perairan naik ke permukaan. Hal ini sesuai pendapat Simanjuntak (2006) menyatakan bahwa tingginya kadar fosfat disebabkan arus dan pengadukan massa air yang mengakibatkan terangkatnya kandungan fosfat yang tinggi dari dasar ke lapisan permukaan, selain itu faktor yang sangat mempengaruhi kandungan fosfat tinggi yakni adanya limbah rumah tangga, 
Hutagalung \& Rozak (1997), menyatakan bahwa sumber antropogenik fosfor berasal dari limbah industri, domestik, dan limbah pertanian.

\section{Nitrat}

Hasil penelitian menunjukkan kandungan nitrat- $\mathrm{NO}^{3}$ pada setiap minggu pengambilan sampel air pada stasiun 1 (Desa Tanrusampe) adalah sama yaitu dibawah dari $0.001 \mathrm{mg} / \mathrm{L}$. Masing-masing nilai tersebut adalah nilai dari hasil reduksi kadmium secara spektrofotometer yang digunakan dalam pengujian sampel air. Sehingga kandungan nitrat- $\mathrm{NO}^{3}$ yang terkandung dalam kawasan budidaya rumput laut stasiun 1 (Desa Tanrusampe) sangat jauh dari batas deteksi dari alat pembacaan kandungan nitrat- $\mathrm{NO}^{3}$ yaitu reduksi kadmium secara spektrofotometer. Sedangkan pada stasiun 2 (Desa Bontosunggu) mendapatkan hasil berbeda pada pengambilan sampel minggu pertama dengan kandungan nitrat- $\mathrm{NO}^{3}$ yang paling tinggi yaitu $0.202 \mathrm{mg} / \mathrm{L}$. Untuk pengambilan sampel minggu kedua sampai minggu kelima dengan hasil yang sama dibawah dari $0.001 \mathrm{mg} / \mathrm{L}$ sangat jauh dari batas deteksi alat pembacaan kandungan nitrat- $\mathrm{NO}^{3}$ yaitu reduksi kadmium secara spektrofotometer, ditunjukkan pada tabel 4.1.

Tabel 4.1. Kandungan Nitrat $-\mathrm{NO}^{3}$ Pada Kawasan Budidaya Rumput Laut

\begin{tabular}{|c|c|c|}
\hline Minggu & \multicolumn{2}{|c|}{$\begin{array}{c}\text { Parameter Nitrat }-\mathrm{NO}^{3} \\
(\mathrm{mg} / \mathrm{L})\end{array}$} \\
\cline { 2 - 3 } & $\begin{array}{c}\text { Sampel 1 } \\
\text { (Desa } \\
\text { Tanrusampe ) }\end{array}$ & $\begin{array}{c}\text { Sampel 2 } \\
\text { (Desa } \\
\text { Bontosunggu })\end{array}$ \\
\hline 1 & $\mathrm{tt}$ & 0.202 \\
\hline 2 & $\mathrm{tt}$ & $\mathrm{tt}$ \\
\hline 3 & $\mathrm{tt}$ & $\mathrm{tt}$ \\
\hline 4 & $\mathrm{tt}$ & $\mathrm{tt}$ \\
\hline 5 & $\mathrm{tt}$ & $\mathrm{tt}$ \\
\hline
\end{tabular}

Ket: $\mathrm{tt}=$ Tidak Terdeteksi $(<0,001)$

Sumber: Data Primer Setelah diolah, 2019

Nitrogen dibutuhkan oleh tanaman untuk proses fotosintesis. Pertumbuhan alga yang baik membutuhkan kisaran nitrat sebesar 0,9 - 3,50 ppm (Andarias, 1992). Selanjutnya ditambahkan oleh Tambaru \& Samawi (1996) bahwa kebutuhan nitrat oleh setiap alga sangat beragam. Apabila kadar nitrat dibawah 0,1 atau diatas 45 $\mathrm{mg} / \mathrm{l}$, maka nitrat merupakan faktor pembatas berarti pada kadar demikian nitrat bersifat toksik dan dapat mengakibatkan terjadinya eutrofikasi yang dapat merangsang pertumbuhan fitoplankton dengan cepat (blooming). Adanya kandungan nitrat yang rendah dan tinggi pada kondisi tertentu dapat disebabkan oleh berbagai faktor, antara lain adanya arus yang membawa nitrat dan kelimpahan fitoplankton (Koesoebiono, 1981).

Bila ditinjau dari kadar nitrat yang merupakan salah satu indikator kesuburan, maka kisaran kadar nitrat di perairan Jeneponto pada stasiun 1 (Desa Tanrusampe) sudah dalam faktor pembatas atau kandungan nitratnya bersifat toksik sedangkan pada stasiun 2 (Desa Bontosunggu) masih berada pada ambang batas kualitas air perairan dan masih layak untuk budidaya rumput laut Eucheuma cottoni.

\section{Plankton}

Hasil identifikasi plankton dan analisis kelimpahan plankton yang dilakukan selama dua kali pengambilan sampel yaitu pada minggu pertama dan minggu kelima (awal-akhir penelitian) pengambilan sampel air pada stasiun 1 (Desa Tanrusampe) dan stasiun 2 (Desa 
JPTP Jurnal Pendidikan Teknologi Pertanian

Bontosunggu) yang disajikan dalam Tabel

4.2 sebagai berikut:

Tabel 4.2. Hasil identifiasi dan kelimpahan plankton

\begin{tabular}{|c|c|c|c|c|c|}
\hline \multirow[t]{2}{*}{ No } & \multirow[t]{2}{*}{ Species } & \multicolumn{4}{|c|}{ Kelimpahan (ind// $\left.\mathbf{L}^{-1}\right)$} \\
\hline & & $\begin{array}{l}\text { P1 } \\
(1)\end{array}$ & $\begin{array}{l}\text { P1 } \\
(5)\end{array}$ & $\begin{array}{l}\mathbf{P 2} \\
(\mathbf{1})\end{array}$ & $\begin{array}{l}\mathbf{P 2} \\
(5)\end{array}$ \\
\hline \multicolumn{6}{|c|}{ Fitoplankton } \\
\hline 1 & $\begin{array}{l}\text { Leptocylindr } \\
\text { icus sp }\end{array}$ & 5490 & 540 & 6570 & 1080 \\
\hline 2 & $\begin{array}{l}\text { Rhizosolenia } \\
\text { sp }\end{array}$ & 1260 & 0 & 2160 & 0 \\
\hline 3 & Flagilaria sp & 2160 & 0 & 0 & 0 \\
\hline 4 & $\begin{array}{c}\text { Thalassione } \\
\text { masp }\end{array}$ & 0 & 0 & 1080 & 0 \\
\hline 5 & $\begin{array}{c}\text { Coscinodisc } \\
\text { us sp }\end{array}$ & 0 & 1080 & 0 & 540 \\
\hline 6 & $\begin{array}{l}\text { Ceratium } \\
\text { fusus }\end{array}$ & 0 & 540 & 0 & 0 \\
\hline 7 & $\begin{array}{c}\text { Pleurosigma } \\
\text { sp }\end{array}$ & 0 & 0 & 0 & 540 \\
\hline \multicolumn{6}{|c|}{ Zooplankton } \\
\hline 8 & $\begin{array}{l}\text { Unidentified } \\
\text { larva } \\
\text { gastropoda }\end{array}$ & 1080 & 0 & 0 & 630 \\
\hline 9 & $\begin{array}{l}\text { Unidentified } \\
\text { larva } \\
\text { polychaeta }\end{array}$ & 540 & 720 & 630 & 0 \\
\hline 10 & $\begin{array}{c}\text { Unidentified } \\
\text { larva } \\
\text { bivalvia }\end{array}$ & 0 & 0 & 1080 & 0 \\
\hline 11 & $\begin{array}{c}\text { Tintinnopsis } \\
\text { sp }\end{array}$ & 0 & 540 & 0 & 0 \\
\hline 12 & $\begin{array}{l}\text { Unidentified } \\
\text { larva udang }\end{array}$ & 0 & 0 & 0 & 540 \\
\hline \multicolumn{2}{|c|}{$\begin{array}{l}\text { Total kelimpahan } \\
(\mathrm{N})\end{array}$} & 10530 & 3420 & 11520 & 3330 \\
\hline
\end{tabular}

Sumber: Data Primer Setelah diolah, 2019

Hasil pengujian kelimpahan plankton pada stasiun 1 (Desa Tanrusampe) diperoleh kelimpahan pada awal pengambilan sampel yaitu 10530 ind/L $\mathrm{L}^{-1}$ dan akhir pengambilan sampel yaitu $3420 \mathrm{ind} / \mathrm{L}^{-1}$. Sedangkan pada stasiun 2 (Desa Bontosunggu) diperoleh kelimpahan plankton pada awal pengambilan sampel yaitu $11520 \mathrm{ind} / \mathrm{L}^{-1}$
Volume 6 Februari, 2020

dan pada akhir pengambilan sampel yaitu $3330 \mathrm{ind} / \mathrm{L}^{-1}$. kedua tempat pengambilan sampel tersebut mengalami penurunan kelimpahan plankton.

Keberadaan atau kelimpahan fitoplankton akan sangat bergantung pada ketersediaan cahaya dalam perairan, semakin banyak cahaya yang masuk ke dalam perairan maka akan semakin tinggi pula keberadaan atau kelimpahan fitoplankton (Heyman \& Lundgren, 1988). Selain itu, kekeruhan air juga akan mempengaruhi pertumbuhan fitoplankton, hal ini karena kekeruhan air akan mempengaruhi cahaya matahari yang masuk ke dalam air (Apriliyanti, 2018). Selain itu $\mathrm{pH}$ sangat mempengaruhi kehidupan makhluk hidup, termasuk didalamnya fitoplankton, $\mathrm{pH}$ yang ideal untuk kehidupan fitoplankton di perairan laut Indonesia umumnya $6,0 \quad-\quad 8,5$ (Asriyana \& Yuliana, 2012).

Berdasarkan nilai keanekaragaman $\left(\mathrm{H}^{\prime}\right)$ plankton Perairan Jeneponto yaitu berturut turut dari minggu pertama dan kelima di kedua stasiun yaitu 1,3045; 1,$5664 ; 1,2369 ; 1,5652$. Sesuai dengan pernyataan Odum (1993) dalam Silalahi (2009), mengenai kriteria indeks keanekaragaman ( $\left.\mathrm{H}^{\prime}\right)$ yaitu: $\mathrm{H}^{\prime}<1=$ keanekaragaman rendah, $1<\mathrm{H}^{\prime}<3=$ keanekaragaman sedang dan H'>3= keanekaragaman tinggi. Sehingga pada perairan ini menunjukkan bahwa indeks keanekaragamannya sedang.

Dari data kelimpahan, keragaman dan dominasi tersebut, dimana berada pada tingkat kestabilan sedang dan tidak tercemar, maka perairan ini layak untuk dijadikan tempat usaha budidaya rumput laut. 


\section{Kesimpulan}

Kualitas air pada stasiun 1 (Desa Tanrusampe) meliputi suhu, kecerahan, kecepatan arus, $\mathrm{pH}$, salinitas, oksigen terlarut, Fosfat, dan plankton masih dalam kategori normal dan masih berada pada ambang batas kualitas air perairan, sedangkan nitrat sudah dalam faktor pembatas atau kandungan nitratnya bersifat toksik. Sedangkan kualitas air pada stasiun 2 (Desa Bontosunggu) masih dalam kategori normal dan masih berada pada ambang batas kualitas air perairan, dan masih layak untuk budidaya rumput laut Eucheuma cottoni.

\section{Daftar Pustaka}

Akib, A., M. Litaay.,Ambeng., \& M.Asnady. 2015. Kelayakan Kualitas Air Untuk Kawasan Budidaya Eucheuma cottoni Berdasarkan Aspek Fisika, Kimia dan Biologi di Kabupaten Kepulauan Selayar. Jurnal Pesisir dan Laut Tropis. 1(1): 25-36

Andarias, I., 1992. Pengaruh Takaran Urea dan TSP Terhadap Produksi Bobot Kering Klekap. Buletin Ilmu Perikanan dan Peternakan.

Andriani, E. D., 1999. Kondisi FisikaKimiawi Air Perairan Pantai Sekitar Tambak Balai Budidaya Air Payau (BBAP) Jepara, Kabupaten Jepara, Jawa Tengah. Skripsi. Fakultas Perikanan dan Ilmu Kelautan, Institut Pertanian Bogor.

Anggadiredja J, Purwoto A \& Istini S. 2011. Seri Agribisnis Rumput Laut. Penebar Swadaya, Jakarta.

Apriliyanti, Margaretha Sandra. 2018. Identifikasi Plaankton dari Kawasan Budidaya Rumput Laut
Kabupaten Bantaeng, Sulawesi Selatan dengan Metode DNA Barcoding. Skripsi. Fakultas Pertanian. Universitas Lampung. Bandar Lampung

Arisandi, P. 2012. Pengukuran Kualitas Air Hulu Daerah Aliran Sungai Kali Brantas Berdasarkan Keragaman Taksa Ephemeroptera, Plecoptera, Dan Tricoptera. Surabaya.

Aslan, L. M. 1998. Budidaya Rumput Laut. Penerbit Kanisius. Yogyakarta.

Asni, A. 2015. Analisis Produksi Rumput Laut (Kappaphycus alvarezii) Berdasarkan Musim dan Jarak Lokasi Budidaya Diperairan Kabupaten Bantaeng. Jurnal Akuatik. Vol. 6, No. 2: 145-148.

Asriyana \& Yuliana. 2012. Produktivitas Perairan. Bumi Aksara. Jakarta.

Effendi, H. 2003. Telaah Kualitas Air Bagi Pengolahan Sumberdaya Hayati Lingkungan Perairan. Kanisius. Yogyakarta

Febriani, R. 2014. Studi Tentang Komposisi Jenis Ddan Kepadatan Organism Penempel Pada Rumpon Sebagai Alat Bantu Penangkapan Ikan Di Perairan Teluk Mallasoro Kabupaten Jeneponto. Skripsi Program Studi Pemanfaatan Sumberdaya Perikanan. Universitas Hasanuddin. Makassar.

Heyman, U. dan Lundgren, A.1988. Phytoplankton Biomass and Production in Relation to Phosphorus Some Conclusions From Field Studies. Hydrobiologia,170 (1): 211-227.

Hutagalung H. P. dan A. Rozak. 1997. Penentuan kadar Nitrat. Metode Analisis Air Laut, Sedimen, dan Biota. H. P Hutagalung, D. 
JPTP Jurnal Pendidikan Teknologi Pertanian

Setiapermana dan S. H. Riyono (Editor). Pusat Penelitian dan Pengembangan Oseanologi. LIPI. Jakarta.

Indriani, H. \& E. Sumiarsih. 1991. Budidaya, Pengelolaan dan Pemasaran Rumput Laut. Penebar Swadaya, Jakarta.

Juniarti, L., M. I. Jumarang, dan Apriansyah. 2017. Analisis Kondisi Suhu dan Salinitas Perairan Barat Sumatera Menggunakan Data Argo Float. Physic Communication. Vol. 1 No.1.

Kotiya, A.S., Gunalan, B., Parmar, H.V., Jaikumar, M.,Dave, T., Solanki, J.B., \& Nayan, P.M. 2011. Growth comparison of the seaweed Kappaphycus alvarezii in nine different coastal areas of Gujarat coast,India. Advances in Applied Science Research, 2(3),99-106.

Koesoebiono, 1981, Plankton dan Produktivitas Bahari, Fakultas Perikanan-Institut Pertanian Bogor, Bogor.

Luning K. 1990. Sea Weeds Their Environment, Biogeography, and Ecophysiology. A Wiley Interscience Publication, John Wiley and Sons, Inc.

Odum, E. P. 1993. Dasar-Dasar Ekologi. Edisi ketiga. Terjemahan: Samigan, T., Srigandono. Fundamentals of Ecology. Third Edition. Gadjah Mada University Press.

Patang, 2010. Faktor-Faktor yang Berpengaruh Terhadap Produksi Budidaya Rumput Laut K. alvarezii di Kabupaten Pangkep. Jurnal Agrisistem, 6 (1): 8-14.

Puslitbangkan. 1991. Budidaya Rumput Laut (Eucheuma sp) Dengan Rakit dan Lepas Dasar. Pusat Penelitian dan Pengembangan Perikanan.
Volume 6 Februari, 2020

Badan Penelitian Pengembangan Pertanian. Jakarta.

Ramdhan, M., T. Arifin., \& I.S Arlyza. 2018. Pengaruh Lokasi Dan Kondisi Parameter Fisika-Kimia Oseanografi Untuk Produksi Rumput Laut Di Wilayah Pesisir Kabupaten Takalar, Sulawesi Selatan. Pusat Penelitian Oseanografi, LIPI.

Silalahi, J. 2009. Analisis Kualitas Air dan Hubungan Dengan keanekaragaman Vegetasi Akuatik di Perairan Danau Toba. Tesis. Sekolah Pascasarjana. Universitas Sumatera Utara. Medan.

Simanjuntak, M., 2006. Kadar Fosfat, Nitrat Dan Silikat Kaitannya Dengan Kesuburan Di Perairan Delta Mahakam, Kalimantan Timur. Pusat Penelitian Oseanografi Lipi. Jakarta.

Sutamihardja, R. T. M. 1978. Kualitas dan PencemaranLingkungan. Fakultas Pascasarjana Institut Pertanian Bogor. 92 hal.

Tambaru, R., dan F. Samawi. 1996. Beberapa Parameter Kimia Fisika Air di Muara Sungai Tallo Kota Makassar. TORANI Universitas Hasanuddin. Makassar.

Wibisono MS. 2005. Pengantar Ilmu Kelautan. Jakarata. Edisi kedua. PT Gramedia Widiasarana Indonesia.

Wibowo, L \& Fitriyani, E. 2012. Pengolahan Rumput Laut ( Eucheuma cottoni) menjadi serbuk minuman instan. Jurusan Ilmu Kelautan dan Perikanan. Politeknik Negeri Pontianak. Jurnal Vokasi. 8(2): 101-109. 